\title{
The distribution of blood cells on haemacytometer counting chambers with special reference to the amended British Standards Specification 748 (1958)
}

\author{
C. SANDERS AND D. W. SKERRY
}

From the Haematology Department, Medical Division, A.E.R.E., Harwell

SYNOPSIS The distribution of leucocytes and erythrocytes on the haemacytometer counting chamber is shown. Differences between total leucocyte counts on single and double-ruled chambers are? given and the effect of different lengths of cover glass are discussed. An assessment of the relative accuracy of the amended British Standards Specification (B.S.S.) 748 (1958) double-ruled brighe line chamber and the old B.S.S. chambers is made.

Hynes (1947) published a detailed account of the leucocyte distribution on the counting chamber, from which it was apparent that the distribution of cells departed considerably from the theoretical expectation that the number of cells on each square of a haemacytometer counting chamber is distributed in a Poisson series (Fig. 1).

Using a Burker single-ruled counting chamber with Neubauer ruling, Hynes counted, as is usual, the number of cells on four areas of one square

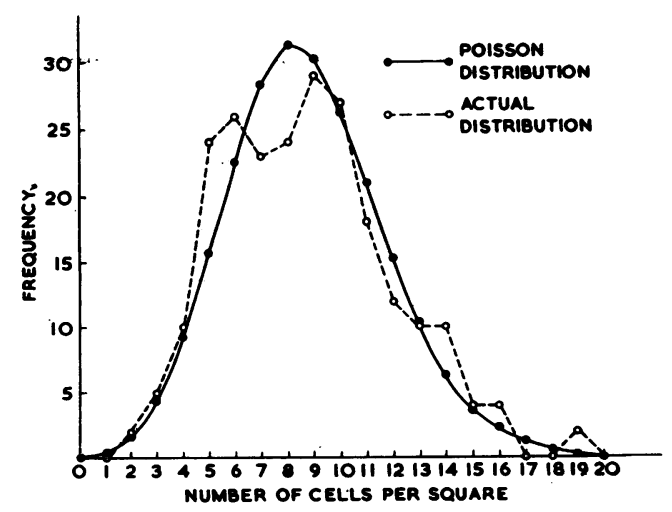

FIG. 1. Comparison of theoretical with actual distribution of leucocytes counted in squares $0.5 \mathrm{~mm} . \times 0.5 \mathrm{~mm}$. over the whole flooded area.

Received for publication 8 September 1960. millimetre at the corners of the ruled area and recorded the four subtotals separately. Over this series of counts the two squares nearest to the filling point of the chamber gave nearly identical totalo $3.5 \%$ below the mean value for all four squares 0 and the two further squares similarly gave nearly $\overrightarrow{\vec{b}}$ identical totals $3.5 \%$ above the mean value.

By counting known areas across the length of the chamber Hynes demonstrated that there was a variation in leucocyte density along the length of the counting chamber, and that the density increaseof progressively from the point of entry of the fluid 3 The curve of the leucocyte density distribution along the flooded area had two maxima and could be expressed statistically by a quartic polynomial witb the mean value for the leucocyte density per unip area being reached at the centre of the chambero Apparently, the position of the ruled area of the chamber did not affect the slope of the leucocytes distribution curve, and the distribution of cells across a narrow segment of the area conformed to a Poisson expectation. Furthermore, the variation in the leucocyte distribution was not due to bending of the cover glass, nor to any change in the ceff distribution in the pipette before the chamber was filled. It appeared to be due to the drift of the leucocytes caused by their initial forward impetus: and the subsequent convection currents. The distrifD bution of red cells on the counting chamber followe similar laws to those of the leucocytes.

Hynes found, and it has been confirmed a. A.E.R.E. (Sanders, 1954), that the leucocyte and red 


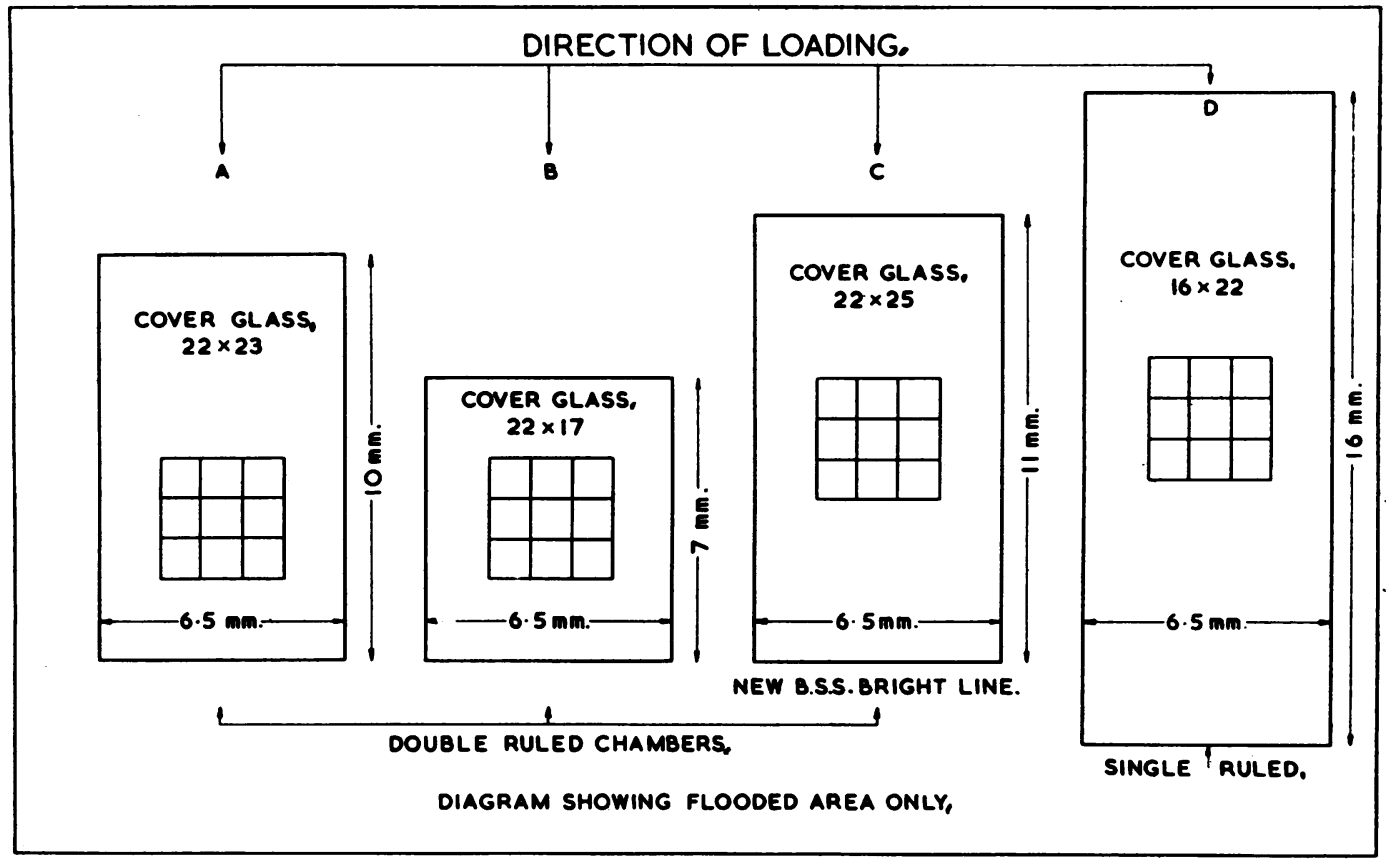

FIG. 2

A The actual flooded area on the old B.S.S. double-ruled chamber with the ruled area in the incorrect position.

B The same chamber with the ruled area in the centre of the flooded area using a $17 \mathrm{~mm} . \times 22 \mathrm{~mm}$. cover $\mathrm{glass}$.

C The amended B.S.S. (1958) metallized bright line double-ruled chamber.

D A single-ruled chamber with $16 \mathrm{~mm} . \times 22 \mathrm{~mm}$. cover glass.

cell distribution on double-ruled counting chambers (with the central trough and two ruled areas) varies in a similar fashion. Again the rule holds that the leucocyte or red cell density reaches its mean halfway along the flooded area. It was clear from this work that the true count is only obtained if cells are counted in equal areas symmetrically disposed about the centre of the flooded area.

Using a single-ruled counting chamber this can easily be achieved if sufficient care is taken to place the cover glass in the correct position, but with the double-ruled counting chamber it is more difficult to ensure that both ruled areas are centrally placed with regard to their respective flooded areas beneath the cover glass. In fact, with the specification and size of cover glass stated in B.S.S. 748 (1937-53), it is impossible to use both sides of the counting chamber at the same time and have each ruling centrally placed with regard to its flooded area. This specification states that the size of cover glass to be used with the double-ruled chamber shall be $23 \mathrm{~mm}$. $\times 22 \mathrm{~mm}$., and that the distance between the centres of the two ruled areas shall be $10 \mathrm{~mm}$. With this size of cover glass symmetrically placed in relation to the central dividing trough, the ruled area of each side is not centrally placed with regard to its flooded area. The mid-line of each ruled area will be $3.5 \mathrm{~mm}$. from the central dividing trough and $6.5 \mathrm{~mm}$. from the outer edge of the cover glass or point of entry of the diluted blood sample (Fig. 2a). As the leucocyte or red cell density reaches its mean value half-way along the flooded area of the chamber the use of this type of counting chamber would result in cell counts being higher by approximately $7 \cdot 5 \%$. To correct this error it would be necessary to reduce the size of the cover glass to $17 \mathrm{~mm}$. $\times 22 \mathrm{~mm}$. (Fig. 2b). However, this would reduce the length of the flooded area to $7 \mathrm{~mm}$.

Hynes has shown that the length of the flooded area has a considerable effect on the slope of the distribution curve. The curve has a steep gradient in the middle third of the filled area, but the steepness decreases as the length of the counting chamber filled increases. With different lengths of flooded area, however, the curves show one important common property, namely, that the cell density reaches its mean value half-way along this area. Using the double-ruled chamber, the position of 
the ruled area would have to be altered and if possible the length of the chamber increased since the longer the area the less would be the error from slight inaccuracies in the position of the rulings.

The error in position of the ruled area and the size of the cover glass was brought to the notice of the appropriate committee of the British Standards Institution, who in 1958 issued amendment No. 2 for B.S.S. 748 in respect of double-ruled counting chambers. These chambers are now made in Great Britain with the distance between the centres of the ruled areas $14 \mathrm{~mm}$. and with a cover glass of $25 \mathrm{~mm}$. $\times 22 \mathrm{~mm}$. This size of cover glass provides a flooded area of $11 \mathrm{~mm}$. in length on each side of the chamber, and ensures that the rulings are centrally placed.

The introduction of the 'metallized bright line' type of chamber has greatly increased the clarity of the rulings, and for cell counts this type of chamber is far superior to the old type of haemacytometer. It is of interest to note that after over two years of daily use these chambers have shown no deterioration in the metallized surface, whereas the rulings on the old type of chamber became faint even after a few months' use.

When the new haemacytometers became available, it was decided to carry out a further series of experiments on the distribution of cells and the relative accuracy of the new and old type of counting chambers.

\section{METHODS}

Blood samples, either venous or capillary, were diluted 1 in 20 for leucocytes with $2 \%$ acetic acid tinted with crystal violet, by means of haemacytometer dilution pipettes, each of which had been checked by the National Physical Laboratory. Only those pipettes giving an exact dilution of 1 in 20 were used. The red cells were diluted 1 in 200 by means of accurate $0.02 \mathrm{ml}$. straight line pipettes, washing the contents into exactly $4.0 \mathrm{ml}$. Wolff's fluid contained in $5 \mathrm{ml}$. plastic stoppered tubes (potassium iodide $26.0 \mathrm{~g}$., iodine $1.0 \mathrm{~g}$. made up to 1,000 $\mathrm{ml}$. with distilled water to which is added $30.0 \mathrm{ml}$. of $1 \%$ aqueous solution of eosin). The contents of the haemacytometer pipettes were thoroughly mixed by placing the pipettes in a magnetic shaker (Sanders, Parry, Bennett, and Geison, 1950) for three minutes. The first few drops of the mixed contents of each pipette were expelled before loading the chambers in the usual way by capillary attraction. The red cell suspensions were mixed by placing the tubes in a rotary shaker for five minutes and a sample of the contents removed by means of a Pasteur pipette. The chambers were loaded as previously stated. Preparations were sealed with vaseline to prevent drying out when counting cells for distribution across the length of the flooded area.
PROBLEM $1 a$ Was the distribution of cells along the length of the flooded area similar to that described by Hynes?

A double-ruled improved Neubauer chamber (ole B.S.S., 1953) was used for this set of experiments (1) withE a cover glass of $17 \mathrm{~mm} . \times 22 \mathrm{~mm}$. providing a flooded area of $7 \mathrm{~mm}$. in length and with the rulings centrally placed; and (2) with a cover glass of $22 \mathrm{~mm}$. $\times 23 \mathrm{~mm}$ ? providing a flooded area of $10 \mathrm{~mm}$. in length with the्छ rulings in the incorrect position.

Experiment 1 Distribution of leucocytes on the double-ruled chamber, flooded area $10 \mathrm{~mm}$. in length $\vec{\omega}$ (Fig. 2a).

Areas of $0.5 \mathrm{~mm}$. square on the counting chamber were defined by means of Ehrlich's eyepieces, and counts were made starting $0.5 \mathrm{~mm}$. from the point of entry of the diluted blood sample across the length of the chambef to within $0.5 \mathrm{~mm}$. of the dividing trough. Twelve sucht rows of counts were necessary to provide a grid opo observations covering the whole of the flooded area은 Five separate loadings were made from the same bloodsample, and the mean for all five counts in each positions of the grid plotted as shown in Fig. 3. It will be seen tha

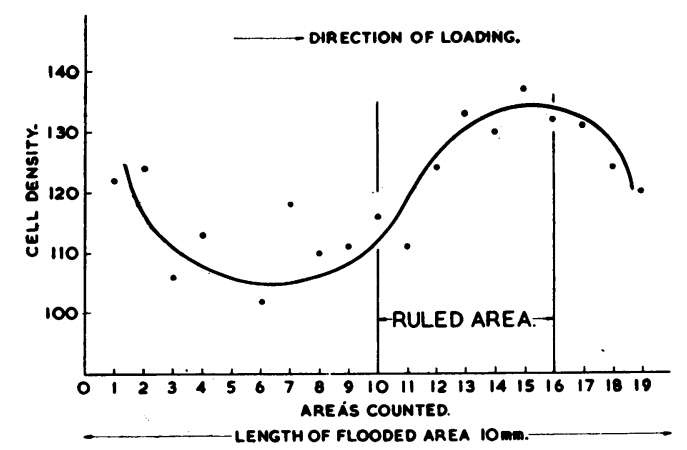

FIG. 3. The leucocyte distribution on the double-rulect. chamber, old B.S.S. (1953), flooded area $10 \mathrm{~mm}$. in length with the ruled area in the incorrect position. The curves are the best fitting quartics; the dots show the observedo values relating to the continuous lines.

the mean distribution of cells is in the centre of the flooded area, but that using this counting chamber with a cover glass of $22 \mathrm{~mm}$. $\times 23 \mathrm{~mm}$., the ruled area is situated in the higher concentration of cells.

Experiment 2 Distribution of leucocytes on the् double-ruled chamber, flooded area $7 \mathrm{~mm}$. in length (Fig. 2b).

Experiment 1 was repeated using the shorter floodedes area and the mean results plotted as before (Fig. 4). The mean concentration of cells is again in the centre of the flooded area, but due to the reduction in size of the cover glass the rulings are centrally placed.

Experiment 3 Distribution of red cells on the double $\frac{\mathbb{\Omega}}{2}$ ruled chamber, flooded area $7 \mathrm{~mm}$. in length (Fig. 2b).

This experiment was similar to experiment 2 , but in this case red cells diluted 1 in 200 were used. Fiveo 


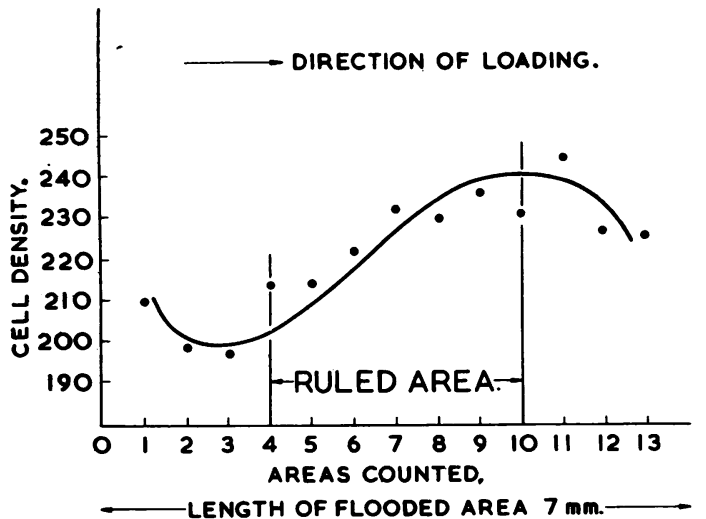

FIG. 4. The leucocyte distribution on the double-ruled chamber, old B.S.S. (1953), flooded area $7 \mathrm{~mm}$. in length, with the ruled area in the correct position. The curves are the best fitting quartics; the dots show the observed values relating to the continuous line.

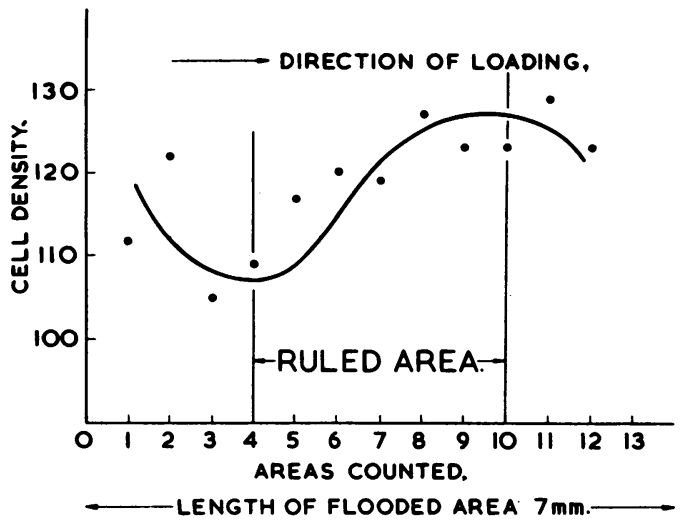

FIG. 5. The red cell distribution on the double-ruled chamber, B.S.S. (1953), flooded area $7 \mathrm{~mm}$. in length, with the ruled area in the correct position. The curves are the best fitting quartics; the dots show the observed values relating to the continuous line.

separate loadings were made from the same sample as in the previous experiments and the mean results plotted (Fig. 5). A similar type of distribution curve to that of the leucocytes was obtained.

PROBLEM $1 b$ Does the length of the flooded area have any effect upon the distribution of the cells?

The length of the flooded area affects the slope of the distribution in that the longer the area the less the slope of the curve. Irrespective of the length of the flooded area the mean value for the cell density is reached half-way along the area.

PROBLem $2 a$ What is the difference between the total leucocyte count made on a single-ruled chamber and that made on the double-ruled chamber with the ruled area in the incorrect position?

Experiment 1 Blood samples were diluted 1 in 20, and mixed as previously described, and the contents of each pipette loaded on to both sides of a double-ruled chamber, old B.S.S. (1953), improved Neubauer, with a cover glass of $22 \mathrm{~mm}$. $\times 23 \mathrm{~mm}$., flooded area $10 \mathrm{~mm}$. in length; and twice on to a single-ruled chamber with a cover glass of $22 \mathrm{~mm}$. $\times 16 \mathrm{~mm}$., flooded area $16 \mathrm{~mm}$. in length. Three trained technicians carried out the counts using $\mathbf{5 0}$ separate blood samples, i.e., 100 counts on each chamber. The cells were counted in the four corner square millimetre areas. The results are given in Table $I$ as the mean of the 50 blood samples.

TABLE I

TOTAL LEUCOCYTE COUNT

\begin{tabular}{lccc} 
Technician & $\begin{array}{c}\text { Single-ruled } \\
\text { Chamber }\end{array}$ & $\begin{array}{l}\text { Double-ruled } \\
\text { Chamber }\end{array}$ & $\begin{array}{c}\text { Difference between } \\
\text { Two Chambers (\%) }\end{array}$ \\
\hline A & 6,050 & 6,720 & $11 \cdot 07$ \\
B & 6,440 & 7,340 & $14 \cdot 00$ \\
C & 6,210 & 7,035 & $13 \cdot 30$ \\
Mean & 6,266 & 7,032 & $12 \cdot 79$
\end{tabular}

The difference of $12.79 \%$ between the results of the counts made on the single-ruled chamber and the doubleruled chamber is greater than was expected. The incorrect position of the rulings in the old B.S.S. double-ruled chamber could give rise to a count higher by approximately $7.5 \%$ than those obtained when the rulings are in the correct position. The additional $5 \cdot 29 \%$ difference suggests that the longer flooded area in the single-ruled chamber has an effect on the total cell count result.

PROBLEM $2 b$ What is the difference between the total leucocyte count made on a single-ruled chamber and that made on the amended B.S.S. double-ruled chamber.

Experiment 2 Twenty-two blood samples were loaded on to both sides of the double-ruled chamber with a cover glass of $25 \mathrm{~mm}$. $\times 22 \mathrm{~mm}$., flooded area $11 \mathrm{~mm}$. in length, and twice on a single-ruled chamber with a cover glass of $22 \mathrm{~mm}$. $\times 16 \mathrm{~mm}$., flooded area $16 \mathrm{~mm}$. in length. One trained technician carried out the counts. The results are given in Table II, as the mean for all the blood samples.

\section{TABLE II}

\section{TOTAL LEUCOCYTE COUNT}

\begin{tabular}{ccc}
$\begin{array}{l}\text { Single-ruled } \\
\text { Chamber }\end{array}$ & $\begin{array}{l}\text { Double-ruled } \\
\text { Chamber }\end{array}$ & $\begin{array}{l}\text { Difference between } \\
\text { Two Chambers (\%) }\end{array}$ \\
\hline 6,300 & 6,650 & 5.6
\end{tabular}

These results show that although the length of the flooded area is $11 \mathrm{~mm}$. on the double-ruled chamber with the rulings centrally placed, there is still a difference of $5.6 \%$ between the counts made on the two chambers.

This difference is similar to that obtained in experiment 
1 but since both ruled areas in the single and doubleruled chambers were centrally placed with regard to the flooded area, this difference cannot be due to incorrect positions of the rulings but due to the difference in length of the flooded area.

PROBLem 2c What is the difference between the total leucocyte count made on the amended B.S.S. doubleruled chamber and that made on the old B.S.S. doubleruled chamber with the ruled area in the incorrect position?

Experiment 3 Three trained technicians carried out the counts, each using $\mathbf{5 0}$ separate blood samples diluted 1 in 20 , loading both sides of each chamber. The results are given in Table III as the mean of the 50 blood samples.

TABLE III

TOTAL LEUCOCYTE COUNT

\begin{tabular}{cccc} 
Technician & $\begin{array}{l}\text { Amended } \\
\text { B.S.S. } \\
\text { Double-ruled } \\
\text { Chamber }\end{array}$ & $\begin{array}{l}\text { Old B.S.S. } \\
\text { Double-ruled } \\
\text { Chamber }\end{array}$ & $\begin{array}{l}\text { Difference between } \\
\text { Two Chambers (\%) }\end{array}$ \\
\hline A & 7,210 & 7,715 & $7 \cdot 0$ \\
B & 5,215 & 5,620 & $7 \cdot 8$ \\
Mean & 6,770 & 7,309 & $8 \cdot 0$ \\
& 6,398 & 6,881 & $7 \cdot 6$
\end{tabular}

$t=6.3$ (50 blood samples) $P=$ less than 0.01

The results show a mean of $7.6 \%$ difference between the two types of chamber. Applying the $t$ test to the results of technician $A$, the probability of the difference between the two means occurring by chance alone is less than one in a hundred. Therefore the difference is unlikely to be due to chance but due to the incorrect position of the ruled area on the old type of chamber.

PROBLEM 3 What is the difference in the total leucocyte count when made using different lengths of flooded area and with the ruled area off centre by 1 and 2 millimetres?

Experiment To compare the error due to different lengths of flooded area, and that due to incorrect positioning of rulings, a series of leucocyte counts was made using three different sizes of cover glass 11,14 , and $17 \mathrm{~mm}$ in length on a single-ruled chamber. For each size of: cover glass a count was made with the ruled area centrally $\overrightarrow{5}$. placed in relation to its flooded area, and also with the cover glass so placed that the rulings would be $1 \mathrm{~mm}$ ? and $2 \mathrm{~mm}$. off centre, i.e., so that the ruled area would be in the more concentrated cell density. The results are given in Table IV, as the mean of five blood samples.

\section{TABLE IV}

Source of Variation

Coefficient of Variation

Between the three lengths of flooded area 11,14 , and $17 \mathrm{~mm}$.

Between the three positions of the ruled area; central, 1 and $2 \mathrm{~mm}$. off centre Random error

$8.8 \%$

$16 \cdot 4 \%$

$12 \cdot 4 \%$

The results show that the variation is greater $(16.4 \%$ when the rulings are incorrectly positioned in relation to the flooded area than it is with different lengths of flooded area $(8.8 \%)$. Although Hynes has shown that the longer $\vec{r}$ the flooded area the less is the error from slight inaccuro acies in the position of the ruling, he has not considered the length of the flooded area as being a factor in the variation between cell counts.

PROBLEM 4 How far off centre are the ruled areas in क selection of the old type of double-ruled chambers and as selection of the new amended B.S.S. double-rule chamber?

Four types of double-ruled chambers-Burker, ordinar 8 Neubauer, improved Neubauer (1937-53), B.S. specifi cation, and the amended B.S.S. 748 (1958) were examinedo The distance between the edge of the central dividing trough and the beginning of the $3 \mathrm{~mm} . \times 3 \mathrm{~mm}$. rule area was measured to within $0.1 \mathrm{~mm}$. by means of a. Zeiss photomicroscope. The results are given in Table to the nearest $0.2 \mathrm{~mm}$.

Of the 20 amended B.S.S. double-ruled chambers measured, the maximum difference between the actuaf and specified position of the ruled area was $0.2 \mathrm{~mm}$. The effect of this small difference on the cell count is negligible.

With the old B.S. specification the ruled area

TABLE V

\begin{tabular}{|c|c|c|c|c|c|}
\hline \multirow{2}{*}{$\begin{array}{l}\text { Actual } \\
\text { Measurement } \\
(\mathrm{mm} .)\end{array}$} & \multirow{2}{*}{$\begin{array}{l}\text { Difference between B.S.S. } \\
\text { and Measurement (mm.) }\end{array}$} & \multicolumn{3}{|c|}{ Type of Chamber } & \multirow{2}{*}{$\begin{array}{l}\% \text { Higher than } \\
\text { Mean Count of } \\
\text { Correct Chamber }\end{array}$} \\
\hline & & Burker & $\begin{array}{l}\text { Ordinary } \\
\text { Neubauer }\end{array}$ & $\begin{array}{l}\text { Improved } \\
\text { Neubauer }\end{array}$ & \\
\hline $1 \cdot 2$ & +0.8 & 1 & 0 & 0 & $13 \cdot 0$ \\
\hline 1.4 & +0.6 & 3 & 0 & 0 & 11.0 \\
\hline 1.6 & +0.4 & 2 & 2 & 7 & 11.0 \\
\hline 1.8 & +0.2 & 1 & 8 & 10 & \\
\hline $2 \cdot 0$ & 0.0 & 1 & 20 & 9 & $6 \cdot 0$ \\
\hline $2 \cdot 2$ & -0.2 & 6 & 9 & 8 & j \\
\hline 2.4 & -0.4 & 1 & 1 & 6 & 4.0 \\
\hline 2.6 & -0.6 & 0 & 0 & 0 & \\
\hline $2 \cdot 8$ & -0.8 & 0 & $\mathbf{0}$ & 0 & \\
\hline 3.0 & $-1 \cdot 0$ & 0 & o & o & \\
\hline $3 \cdot 2$ & $-1 \cdot 2$ & 0 & 0 & 0 & \\
\hline $3 \cdot 4$ & -1.4 & 1 & 0 & $\mathbf{0}$ & 0.0 \\
\hline \multicolumn{2}{|c|}{ No. of ruled areas examined } & 16 & 40 & 40 & \\
\hline
\end{tabular}


$3 \mathrm{~mm}$. $\times 3 \mathrm{~mm}$. should start at $2.0 \mathrm{~mm}$. from the dividing trough and with the new specification $4.0 \mathrm{~mm}$. The results show that apart from the fact that the position of the rulings on the old chambers differ from the specification, there is also considerable variation among a selection of the same type of chamber.

\section{DISCUSSION}

Hynes (1947) has shown, and it has been confirmed in this department, that the density of cells per unit area on the counting chamber increases progressively from the point of entry of the fluid along the length of the flooded area; that the mean cell density per unit area is reached at the centre of the flooded area of the chamber and that the rate of change in the cell density is less the longer the filled area of the counting chamber, in other words, the less the slope of the cell distribution curve.

In order to obtain accurate counts it is essential to count the cells in equal areas symmetrically disposed about the centre of the flooded area. Therefore it is important that with double-ruled chambers the position of the rulings and the size of cover glass must be clearly specified so that the haemacytometer will be manufactured to within accurate limits. Measurements made on the amended B.S.S. double-ruled chambers have shown that these tolerances are being adhered to.

Hynes found that with a flooded area of $9.0 \mathrm{~mm}$. in length, the leucocyte density per unit area changed at the rate of $5 \%$ per $\mathrm{mm}$. at the centre, whereas with a flooded area of $26.0 \mathrm{~mm}$. in length the rate of change was only $2 \%$ per $\mathrm{mm}$. Thus the longer the area of the counting chamber filled, the less would be the error from small inaccuracies in placing the cover glass centrally over the rulings.

With the double-ruled chambers the length of the flooded area on each side of the chamber is restricted by the overall dimensions of the haemacytometer. Allowance must be made for a small plateau at the outer edge of each side of the chamber in order to load the diluted blood sample by capillary attraction. The cover glass cannot therefore be increased in size beyond $25.0 \mathrm{~mm}$. in length. This size of cover glass allows for a flooded area of $11.0 \mathrm{~mm}$. on each side of the chamber with $3.0 \mathrm{~mm}$. to cover the dividing trough between the two rulings.

It has been shown that counts made from the same blood sample on the amended B.S.S. doubleruled chamber give results of $5.6 \%$ higher when compared with those made on a single-ruled chamber with a flooded area of $16.0 \mathrm{~mm}$. in length; and that when made on the old B.S.S. (1953) improved Neubauer double-ruled chamber with the rulings in the incorrect position, and a single-ruled chamber the difference was of the order of $12.79 \%$.
Although the mean cell density is reached at the centre of the flooded area irrespective of its length, there does appear to be an effect on the cell count depending upon the length of the flooded area. Little consideration appears to have been given to the fact that irrespective of whether it is a singleruled or double-ruled chamber there are two constant dimensions which are common to both haemacytometers, the depth of the chamber $0.1 \mathrm{~mm}$. and the width of the flooded area $6.0 \mathrm{~mm}$. It is our opinion that there is probably an optimum length of flooded area, taking into consideration these two fixed dimensions, and that approximately twice the width of the flooded area would be a reasonable length for good loading and distribution of cells by the capillary attraction method. It is more difficult to load correctly, without streaming, a long narrow segment by capillary attraction.

A selection of the amended B.S.S. double-ruled chamber examined by the National Physical Laboratory with regard to accuracy of depth and other parameters showed that they are now being manufactured to within the tolerance stated by the British Standards Institution. It is our opinion that providing the cover glass is centrally placed on the chamber and due care is taken when loading the blood sample, accurate counts can be obtained with this haemacytometer.

\section{CONCLUSIONS}

Use of the old B.S.S. double-ruled chamber with the rulings in the incorrect position gives rise to cell counts higher by approximately $7.6 \%$ than those obtained using the amended B.S.S. double-ruled chamber with the rulings in the correct position.

Cell counts made on a single-ruled chamber with a flooded area of $16 \mathrm{~mm}$. in length are approximately $5.6 \%$ lower than those made on the amended B.S.S. double-ruled chamber with a flooded area of $11 \mathrm{~mm}$. in length.

It appears that there must be an optimum length of flooded area for accurate cell counts on haemacytometer counting chambers when loading the diluted blood sample by the capillary attraction method. Taking into consideration the two constant dimensions, the width and depth of the flooded area, we feel that approximately twice the width is the optimum length.

The amended B.S.S. double-ruled bright-line chamber is now manufactured in Britain to a high degree of accuracy. Provided that care in positioning the cover glass and loading diluted blood sample is taken reliable cell counts can be obtained using the haemacytometer. 
SUMMARY

The density of cells per unit area on the counting chamber increases progressively from the point of entrance of the sample along the length of the chamber.

Irrespective of the length of the flooded area the cell density reaches its mean half-way along the chamber. The longer the flooded area the less is the slope of the distribution curve.

The results of total leucocyte counts made on single-ruled and double-ruled chambers show that the increased length of flooded area on the former gives rise to a lower count.

Measurements on a selection of the old type of double-ruled chambers show that the position of the ruled areas varies considerably from chamber to chamber but that the rulings on the amended B.S.S double-ruled chambers is accurate to within the $\stackrel{\vec{\sigma}}{\vec{\sigma}}$ British Standards specification.

It is suggested that there is an optimum length of $\overrightarrow{\overline{\vec{m}}}$ flooded area for a standard width and depth ofo chamber when loading by the capillary attraction음 method.

We are indebted to Mr. B. D. Cook and Mr. D. J. Cotchin for performing many of the counts, to otheres members of the Haematology Department for their $\vec{\circ}$ help, to Dr. R. G. Orr for much helpful criticism in thepreparation of this paper, and to Dr. Katharine Williams, $\vec{\omega}$ Principal Medical Officer, for her permission to publish the paper.

\section{REFERENCES}

Hynes, M. (1947). J. clin. Path., 1, 25.

Sanders, C. (1954). Unpublished work.

—, Parry, K. C., Bennett, A. E., and Geison, J. C. H. (1950). J clin. Path., 3, 367.

\section{The March 1961 Issue}

\section{THE MARCH 1961 ISSUE CONTAINS THE FOLLOWING PAPERS}

Mortuary design and hazards

Sclerosing osteogenic sarcomatosis LIONEL WOLMAN

Pathological changes in temporal arteries removed from unselected cadavers R. W. AINSWORTH, G. A. GRESHAM, and G. V. BALMFORTH

The pathology of 111 cases of primary hepatic malignancy collected in the Liverpool region A. H. CRUICKSHANK

The cytology of gastric mucosa $\quad$ w. c. D. RICHARDS and A. I. SPRIGGS

The adhesiveness of native platelets and its prevention J. R. O'BRIEN

A note on platelet adhesiveness in ischaemic heart disease P. J. NESTEL

The application of $x$-ray diffraction and electron microscopy to the study of human peripheral nerve obtained by biopsy J. B. FINEAN and A. L. WOOLF

A haemagglutination test for anti-Panton-Valentine leucocidin in serum: an interim report on 200 cases A. G. TOWERS

Quantitative determination of haemoglobin $\mathbf{A}_{2}$ using paper electrophoresis R. N. IBBOTSON and B. A. CROMPTON

The relationship to age and cerebral vascular accidents to fibrin and fibrinolytic activity R. HUME

The occurrence of post- $\gamma$ protein in urine: a new protein abnormality ELIZABETH A. BUTLER and F. V. FLYNN
Physico-chemical and immunological observations ond the abnormal proteins in three patients with cryoglobulin- $\frac{}{\mathrm{D}}$ aemia H. A. ELLIS and D. R. STANWORTH with the technical assistance of P. RATCLIFF

The effect of corticotrophin zinc on plasma 17-hydroxycorticoids as a test of adrenal cortical function J. $S$. JENKINS

The influence of penicillin on Lactobacillus leichmannito serum $B_{12}$ assay BORYS BOCZAROW

Human listeral meningitis I. M. LIBRACH and R. K. SETH. Death of an infant in hyperthermia after vaccination K. APOSTOLOV, T. H. FLEWETT, and the late K. S. THOMPSON

Technical methods:

Determination of packed cell volume by centrifugation R. F. JONES

Tris buffer for differentiation between haemoglobins $C_{\mathscr{O}}^{N}$ and $E$ and separation of haemoglobins $S$ from $F$ and 'lepore' from A H. LEHMANN and A. SHARIH

A simple spectrophotometric method for the deter- $\omega$ mination of urea in blood and urine T. K. WITH, TOVE DREYER PETERSEN, and BIRGIT PETERSEN

A method for the collection of saliva P. J. cousins A rapid method for the estimation of serum haptoglobin? D. S. ROWE

Symposium on anticoagulant therapy

Book reviews

Copies are still available and may be obtained from the PUBLISHING MANAGER, BRITISH MEDICAL ASSOCIATION, TAVISTOCK SQUARE, W.C.1, price $17 \mathrm{~s} .6 \mathrm{D}$. 